\title{
The influence of second language learning on speech production by Greek/English bilinguals
}

Niki-Pagona Efstathopoulou

Department of Linguistics, Simon Fraser University, Canada

https://doi.org/10.36505/ExLing-2006/01/0025/000025

\begin{abstract}
This study examined 20 Greek/English bilinguals, living in the Vancouver area, Canada. The duration of aspiration for the three voiceless stops $(/ \mathrm{p} /, / \mathrm{t} /, / \mathrm{k} /)$ and for the following vowel for a series of Greek and English stimuli were analyzed. Factors such as the Age of Arrival (AOA), Age of Learning (AOL), Length of Residence (LOR), everyday use of Greek and English and self-estimated proficiency in both languages were taken into consideration. A number of English sentences produced by the same speakers were also collected and rated for accentedness by native speakers of English. The degree of accent of the bilingual subjects were also exam-ined along with the data collected. The main focus of the study is to see how the interaction of first language (L1) and second language (L2), if any, is observed con-cerning VOT (voice onset time) and following vowel duration.
\end{abstract}

\section{Introduction}

The focus on this study is the comparison of Greek and English VOT (Voice Onset Time) for voiceless stops consonants $/ \mathrm{p} /, / \mathrm{t} / \mathrm{h} / \mathrm{k} /$ produced by Greek/English bilinguals. VOT was examined in the initial stressed syllable of disyllabic Greek and English words. Thus, the factors of stress and syllable ordering were controlled. The interaction between the L1and L2 phonological systems was also explored. Factors correlating with VOT production were also taken into consideration such as the AOA (Age of Arrival), AOL (Age of Learning), LOR (Length of Residence), Education level, everyday use of Greek and English and self-estimated proficiency in both languages. The participants also read a number of sentences that were judged for accentedness by a group of native English speakers.

The expected results are that L1 affects L2 and the other way round, thus VOT in both L1 and L2 are expected to deviate from the average performance of monolinguals. Also, it is expected the accent-ratings to correlate with the degree of shift in the production of VOT. The stronger the accent that a subject has, the least affected is expected to be the Greek VOT by English/L2 and its English VOT is expected to be more affected by Greek/L2.

ExLing 2006: Proceedings of 1st Tutorial and Research Workshop on Experimental Linguistics, 28-30 August 2006, Athens, Greece 


\section{Theoretical background}

This study follows Flege's Speech Learning Model (SLM), (Flege, 1987, 1992, 1995), as well as Best's (1993) Perceptual Assimilation Model (PAM).

\section{Methodology}

The participants in this study were $20 \mathrm{Greek} /$ English bilinguals living at the time in the Greater Vancouver area, BC, Canada. Greek was their first language (L1) and English was their second language (L2). There were 11 male and 9 female subjects, mean age $=58$, (range $=39-78)$ who had been living in an English speaking environment for at least 16 years (range=16-50, mean $=35$ ).

The recordings were made in the quietest room in the participants' house or working place by the same Greek speaking researcher using a tape recorder; the data were later digitized at $44 \mathrm{KH}$ and 16 bits. The procedures were conducted mostly in the Greek language, except when the participant him/herself shifted to English. The participants first signed a consent form and then completed a language background questionnaire, where information such as their profession and age, AOA, AOL, LOR, Education level, selfestimated proficiency in both languages and self-estimated everyday use of Greek were collected.

Then, the participants wearing a head-mounted microphone read a list of 20 Greek and 20 English disyllabic words. Each list was read three times. The English stimuli were read in the carrier phrase "I say again", while the Greek carrier phrase was "Ipa pali". Therefore, the data collected were [20X15X3] $=900$ instances of VOT and vowels for Greek and English respectively. At the end of the session, the participants read three English sentences ${ }^{1}$ three times so the data collected were [20X3X3] $=180$ sentences.

In the accentedness experiment four native speakers of English rated the sentences for accentedness using a 9-point scale ranging from $1=$ no accent to $9=$ extremely strong accent (mean age $=40$, range $26-59$ ). The researcher scanned the sentences for overall quality selecting three from each subject, so the stimuli presented were $20 \times 3=60$. The stimuli were randomized for each of the three times that each judge listened to them.

\section{Results - discussion}

As shown in studies of Italian/English (MacKay \& al, 2001), French/English (Flege, 1987, 1991), English/Portuguese (Major, 1992), Greek/English bilinguals (Efstathopoulou, 2006), it is expected that the bilingual subjects will produce intermediate VOT values for English VOT, because of L1 influence, but also Greek VOT values longer than those of monolinguals because 
of L2 influence. The influence is expected to be similar for vowel length. However, the VOT-to-vowel ratio will be examined. Since values for Greek VOT (Fourakis, 1986) and vowels (Hawks \& Fourakis, 1995), are shorter in comparison with the English ones (Klaat, 1975, Lisker \& Abramson, 164, 1967).

Also, the accent rating of the subjects will be taken into account along with the VOT and vowel measurements. The four native speakers/judges gave accent rating for the 20 bilingual subjects, as shown in the following table along with the subjects' age, age of arrival, length of residence, estimated percentage of use of Greek.

Table 1. Accent ratings.

\begin{tabular}{|l|l|l|l|l|l|l|}
\hline SJ\# & Age & AOA & AOL & LOR & \% of Use & Overall Mean \\
\hline G1 & 65 & 27 & 20 & 38 & 40 & 7.28 \\
\hline G2 & 62 & 20 & 20 & 42 & 20 & 4.33 \\
\hline G3 & 71 & 25 & 17 & 46 & 90 & 6.67 \\
\hline G4 & 39 & 23 & 16 & 16 & 60 & 6.94 \\
\hline G5 & 39 & 21 & 4 & 18 & 40 & 1.58 \\
\hline G6 & 42 & 25 & 10 & 17 & 15 & 3.22 \\
\hline G7 & 57 & 24 & 12 & 33 & 50 & 5.78 \\
\hline G9 & 55 & 27 & 28 & 28 & 80 & 2.22 \\
\hline G10 & 68 & 18 & 18 & 50 & 60 & 6.47 \\
\hline G11 & 57 & 19 & 14 & 38 & 60 & 7.19 \\
\hline G12 & 62 & 23 & 23 & 39 & 40 & 5.33 \\
\hline G13 & 60 & 27 & 15 & 33 & 0.5 & 7.00 \\
\hline G14 & 55 & 22 & 14 & 33 & 50 & 5.42 \\
\hline G15 & 64 & 19 & 19 & 45 & 60 & 5.58 \\
\hline G16 & 65 & 27 & 27 & 38 & 95 & 7.64 \\
\hline G17 & 57 & 19 & 19 & 38 & 95 & 8.22 \\
\hline G18 & 52 & 17 & 14 & 35 & 30 & 4.67 \\
\hline G19 & 61 & 32 & 16 & 29 & 80 & 5.78 \\
\hline G20 & 54 & 15 & 13 & 39 & 70 & 5.69 \\
\hline G21 & 78 & 29 & 20 & 49 & 10 & 7.33 \\
\hline & & & & & \\
\hline
\end{tabular}

\section{Notes}

1. The sentences, a subset from Munro \& Derwing (1995) were: a) The Queen of England lives in London, b) Some people love to eat chocolate, c) Ships travel on the water. 


\section{Acknowledgements}

I thank my subjects for their collaboration. I am grateful to my supervisor Dr. Munro for his constant guidance and support. I am solely responsible for any mistakes.

\section{References}

Efstathopoulou, P.N. 2006. The influence of second language learning on speech production by Greek/English bilinguals: A pilot study, the case of VOT, Presented at NWLC 2006.

Flege J. E. 1992 "Speech Learning in a second Language" in Phonological Development, Models, Research, and Applications, ed. By C. Ferguson, L. Menn, and C. Stoel-Gammon, Parkton MD: York Press, 565-604

Flege J. E. 1987. The production of 'new' and 'similar' phones in a foreign language: evidence for the effect of equivalence classification. Journal of Phonetics $15,45-67$.

Flege J. E., 1991. Age of learning affects the authenticity of voice onset time (VOT) in stops consonants produced in a second language. Journal of Acoustical Society of America 89, 395-411.

Flege J. E. 1995. Second language speech learning: theory, findings and problems. In W. Strange, ed., Speech Perception and Linguistic Experience: Issues in Cross-language Research. Timonium, MD: York Press, 237-277.

Fourakis, M. 1986. A timing model for word-initial CV syllables in Modern Greek. Journal of the Acoustical Society of America 79, 1982-1986.

Hawks, J. \& Fourakis, M., 1995. The Perceptual Vowel Spaces of American English and Modern Greek: A Comparison. Language and Speech 38 (3), 237-252.

Klatt, D. 1975. Voice onset time, frication and aspiration in word-initial clusters. Journal of Speech and Hearing Research 18, 686-705.

Ladefoged, P. 1993. A course in Phonetics, 3rd ed., Harcourt Brace \& Company.

Lisker, L. \& Abramson, A., 1964. A cross-language study of voicing in initial stops: Acoustical measurements. Word 20, 384-422.

Lisker, L. \&Abramson, A., 1967. Some effects of context of voice onset time in English stops. Language Speech 10, 1-28.

Major, R, 1991. Losing English as a first language. The Modern Language Journal, 76, 190-208.

McKay I., Flege J., Thorsten P. \& Carlo S.. 2001. Category restructuring during second-language speech acquisition", Journal of Acoustical Society of America, 110(1), 516-528.

Munro M. \& Derwing T. 1995, "Processing time, accent, and comprehensibility in the perception of native and foreign accented speech." Language and Speech 38 (3), UK: Kingston Press Services, 289-306. 